\title{
Reputation Oversight by the Sharia Supervisory Board Toward Wakalah Contract Application on Murabahah Financing
}

\author{
Bagya Agung Prabowo ${ }^{1 *}$ \\ ${ }^{1}$ Faculty of Law of Universitas Islam Indonesia \\ "Corresponding author. Email: bagya.agung@uii.ac.id
}

\begin{abstract}
As we know that the Sharia Supervisory Board (DPS) has a very important role in overseeing various sharia banking products and operations. DPS will oversee violations of sharia principles which will tarnish the reputation and credibility of sharia banking. Various challenges faced by the Islamic banking system such as in supervising the application of wakalah contracts on murabaha financing to be in accordance with sharia principles. DPS as an institution that is authorized to oversee the alignment of Islamic banking operations with the DSN fatwa is shrouded in a number of issues. First, until now, there is no specific law that is used as a reference for supervision of Islamic banking cases. Second, there is no authority to act decisively on the results of supervision. DPS can only give warnings but cannot close down banking business problems, and supervision by DPS has been ignored. Third, moreover, DPS is appointed and paid by Islamic banks. Things like influencing process control and result control are misleading, just formalities. This is not the right way to maintain the reputation of Islamic banks in providing services in accordance with Islamic principles. To overcome various problems, this study adopted an analytical method based on doctrinal content, by applying four types of legal approaches, namely: (i) historical/historical; (ii) fiqh/philosophy; (iii) comparison; and (iv) analytical and critical. In addition, a harmonious approach is needed to harmonize the reputation of supervision of the application of the wakalah contract to murabahah financing to conform to sharia principles. Keywords: supervision reputation, wakalah agreement, murabahah financing
\end{abstract}

\section{INTRODUCTION}

\subsection{Background}

It cannot be denied that Islam is a complete and universal living system to compile and provide dynamic and easy direction for all aspects of life, including business and financial transactions It cannot be denied that Islam is a complete and universal living system to compile and provide dynamic and easy direction for all aspects of life, including business and financial transactions [1]. The Islamic banking industry is actually run based on Islamic principles and systems. Therefore, the suitability of Islamic banking products and operations with Islamic principles is a fundamental tool in Islamic banking [2]. Basically, Islamic banks have three main functions, namely collecting funds from the public in the form of deposits and investments, channeling funds to the public who need funds from banks and providing services in the form of Islamic bankingservices [3]. In carrying out its main function, Islamic banks have risks, especially in channeling funds to the public. One of them is financing risk, which is the risk caused by the failure of opposing parties to fulfill their obligations, risks related to financing products and related company funding [4].
The majority of Indonesia's population who are Muslim is a profitable captive market for the development of Islamic banking. Captive market means that the majority of the population has psychological sentiments to prioritize the use of Islamic bank services because of the security (halal) offered, of course, with a note that the services and facilities possessed by Islamic banks also do not disappoint [5]. Broadly speaking, the form of operational activities of Islamic banks is divided into three parts in the form of products issued by Islamic banks, each of which is a product of collecting public funds, product distribution of public funds and products related to banking services provided to costumers [6].

\subsection{Statement of the Problem}

Prohibitions that must be shunned in basic and philosophical principles are regulated in the Qur'an and Sunnah. So what needs to be done is to identify things that are forbidden by Islam. In addition, everything is permissible and we can do as much innovation and creativity as possible [7]. For this purpose all banks operating with the sharia system must have an independent internal institution, specifically tasked with ensuring that the bank runs according to Islamic sharia, as mandated in UU No. 40/2007 concerning Limited Liability Companies and UU No. 21/2008 concerning Islamic Banking which states that Islamic banks must have 3 Sharia Supervisory 
Board (DPS). The role of DPS is very strategic in the practice of sharia compliance in Islamic banking institutions in Indonesia.

If we pay close attention, etimology lughawi supervision means riqabah meaning lughawi guarding, organizing and monitoring, as the word of God in surah An-Nisa: 1, Verily, Allah is always watching over you. Supervision in the sense of the term sharia means monitoring (isyraf), examination (muraja'ah) and investigation (fahsh) aimed at preserving benefits (mura'at maslahah) and avoiding destruction ('idra mafsadah) [8]. The term Oversight according to the Indonesian Big Dictionary (KBBI) comes from the words of caution that intends to pay attention to be seen properly, in the sense of seeing things carefully and thoroughly, activities that are nothing more than providing a report based on the actual reality of what is being watched [9]. Whereas in English it is called controlling which is translated as supervision and control, so that the term controlling means broader than supervision, but among experts it has been equated with the notion of controlling with supervision, so supervision includes control. Control comes from control, so as to imagine direct control, wrong repair activities and straightening the right direction [10]. The function and role of DPS in sharia banks has a strong relationship with the management of sharia banking risks, namely reputation risk which further gives an impression of other risks, such as liquidity risk. Sharia banking activities must apply sharia principles in economic transactions and apart from things that are prohibited by Islam such as usury, gambling, speculation and others [11]. Every contract in business activities, especially contracts for the collection and distribution of funds at this time has been regulated in PBI No. 7/46 / PBI / 2005 concerning Collecting and Payment Agreements for Running a Bank Business Based on Sharia Principles [12]

\subsection{Research Questions}

Based on the description above, the issues to be examined in this study are: how is the reputation of the Sharia Supervisory Board (DPS) reputation for the application of the wakalah contract on murabaha financing in Islamic banking?

\subsection{Objectives of Study}

The purpose of this research is to find out and analyze the reputation of the Sharia Supervisory Board (DPS) for the application of wakalah contract on murabaha financing in Islamic banking.

\section{RESEARCH METHODS}

This research is a normative legal research, namely research conducted on the principles of law, legal methods in the sense of value (norm), concrete legal regulations and the legal system related to the material under study [13]. The research approach used is: a. The statutory approach, that is, done by examining the laws and regulations relating to the issues discussied [14]; b. The conceptual approach, done by examining the views of experts relating to the issues discussed. This approach is used when the rule of law does not exist or does not yet exist [15] so that the views of the experts become one of the bases in strengthening the view of researchers; c. The comparative approach, done by holding a legal comparison. Comparative law is very useful because by comparing it can reveal the background of the existence of legal provisions so that it can be a recommendation for the preparation of legislation in accordance with the discussion of researchers [16]. Malaysia was chosen as a comparison country because it has longer and more complete Sharia banking regulations.

\section{LITERATURE REVIEW}

Research with a focus on studies of the Sharia Supervisory Board's reputation for the application of wakalah on murabaha financing in sharia banking is to identify, describe the supervision of the Sharia Supervisory Board on the application of the wakalah contract on murabaha financing and analyse whether it is in accordance with the principles of sharia compliance. To the knowledge of researchers, has not been studied in depth by legal researchers, both studies that lead to theoretical and practical levels. Previous studies discussing the supervision of the Sharia Supervisory Board do not appear to be complete with the variable wakalah application on murabaha financing. Therefore the affirmation of the authenticity of this research is intended to avoid repetition or duplication of themes with the same study focus. Duplicating or repeating the study will not make a significant contribution to the development of legal science, both theoretically and practically.

Tracing of previous studies to determine the originality of this study is carried out by tracing the results of previous research (literature review), both those that have been done by researchers from within the legal disciplines themselves and outside the legal sciences, especially science social Sciences. Some relevant research that has been successfully collected by researchers as a comparison of previous studies is to show the originality of this study.

Yassar Widyanto [17] in 2016 conducted a study entitled "Murabaha bil Wakalah in Micro Financing in BRI Syariah KCP Kudus" The results of his research are micro financing is financing provided by Islamic banks to small and micro entrepreneurs and low-income people who are not served by formal financial institutions and which have been marketoriented for business purposes.

Ahmad Fuad Noor Gufron [18] in 2016 conducted research with the title "Construction of Murabahah Agreement in the DSN-MUI Fatwa Perspective NO.04 / 2000 at BMT El Bana Ngaliyan Semarang" The results of his research Baitul Maal W Tamwil (BMT) is an Islamic financial institution (LKS) which the scope is micro and must comply with Islamic (sharia) law. LKS must have supervision in terms of management and in terms of supervision of its products, whether in accordance with sharia or not, as well as the application of the contracts used. Financing at BMT El Labana Ngaliyan Semarang has several types of financing, 
one of which is Murābahah financing. The role of supervision of the willingness of micro LKS products is carried out by the internal Sharia Supervisory Board of the institution whose independence and credibility need to be re-evaluated. While coordination with the National Sharia Council on oversight of micro LKS products has not been maximal.

Windi Yusmalanim [19] conducted a study in 2017 with the title "Implementation of wakalah contract on Murabaha Financing for Working Capital" The result of the research was the implementation of wakalah contract to buy goods that are objects of murabaha financing for working capital after the murabahah contract and wakalah contract were formally agreed upon. After the murabahah contract and time are agreed upon, after that the customer as a representative of the bank buys goods that are the object of murabahah financing for working capital. After that the contract is implemented, then the obligation of the customer as a representative is to provide proof of purchase of goods in the form of receipts, invoices or notes. However, often the customer does not provide complete evidence, even does not provide proof of purchase of goods to the bank.

\section{RESULTS AND ANALYSIS}

Violations of sharia compliance, which are left by DPS or escaped from the supervision of DPS, will clearly damage the image and credibility of Islamic banks in the eyes of the public, so as to reduce public confidence in Islamic banks. Islamic banks as collectors and distributors of public funds must have a high level of trust in society and in the business world. This reputation is not an easy thing, but it must be cultivated with discipline and seriousness. If the mandate has been reached, efforts to maintain this status are also not easy. One small thing that can sue belief and, in turn, will turn into disaster [20].

For this reason, the role of DPS in Islamic banks must be truly optimized, qualifications to become DPS must be tightened, and the formalization of their roles must be realized in the Islamic banks. According to UU No. 40/2007 Article 109, it states:

a. Companies that conduct business based on sharia principles in addition to having a Board of Commissioners have a Sharia Oversight Board.

b. The Sharia Supervisory Board as referred to in paragraph (1) consists of one or more shariah experts who are appointed by the GMS on the recommendation of the Indonesian Ulama Council (MUI).

c. Sharia Supervisory Board as referred to in paragraph (1) is instructions and advice to the Directors and oversees the activities of the Company to comply with Islamic principles.

Based on this deed, every legal entity or company operating based on sharia principles should have a DPS. Therefore, UU No. 21/2008 Article 32 mentions:

a. Sharia Supervisory Board should be established in Sharia Banks and Conventional Commercial Banks that have Sharia Business Units (UUS).

b. The Sharia Supervisory Board as referred to in paragraph (1) is determined by the General Meeting of
Shareholders on the recommendation of the Indonesian Ulema Council.

c. The Sharia Supervisory Board as referred to in paragraph (1) has the duty to provide advice and advice to directors as well as supervise bank activities in order to comply with Sharia principles.

d. Further provisions regarding the establishment of the Sharia Supervisory Board as referred to in paragraph (1) are regulated by Bank Indonesia.

Based on Article 32 of Sharia Banking Law, sharia banking must establish DPS as mandated by UU No. 21/2008 concerning Islamic Banking.

\subsection{Responsibilities of the Sharia Supervisory Board (DPS)}

Sharia Supervisory Board (DPS) in sharia banking has an important and strategic role in sharia supervision in sharia banking. DPS is responsible for ensuring all Islamic bank products and procedures are in accordance with Islamic principles [21]. Because of its important role in DPS, both laws in Indonesia include the needs of DPS in companies based on sharia and Islamic banking institutions, namely UU No. 40/2007 concerning Limited Liability Companies and UU No. 21/2008 concerning Islamic Banking. Therefore, legally the Sharia Supervisory Board (DPS) in banking institutions has a very strong position, because its presence is very important and strategic.

Optimizing the role of DPS is very important to ensure every transaction is in accordance with sharia principles that refer to the Qur'an and Sunnah, in this case, the fatwa of the National Sharia Council of the Indonesian Ulema Council. The basic guidelines of DSN MUI Chapter IV paragraph 2 states that DSN MUI issues fatwas that bind DPS in every Islamic financial institution and becomes the basis for the parties to take related legal actions, that is based on the fatwa issued by DSN MUI referred by DPS. The existence of DPS mentioned in Article 32 of UU No. 21/2008 basically DPS should be established in Islamic banks and conventional banks that have Islamic business units, they are appointed by the General Meeting of Shareholders on the recommendation of the Indonesian Ulema Council. The Sharia Supervisory Board is assigned to advise the directors and supervise the activities of the bank to conform to sharia principles [22].

UU No. 40/2007 Article 109 states:

a. Companies that run businesses based on sharia principles in addition to having a Board of Commissioners have a Sharia Oversight Board.

b. The Sharia Supervisory Board as referred to in paragraph (1) should consist of one or more shariah experts appointed by a General Meeting of Shareholders on the recommendation of the Indonesian Ulema Council.

c. The Sharia Supervisory Board as referred to in paragraph (1) will provide instructions and advice to the Director and oversee the company's activities to comply with Islamic principles.

Under this law, companies with limited liability companies should have a Sharia Supervisory Board. Therefore, UU No. 21/2008 Article 32 mentions: 
a. Sharia Supervisory Board should be established in Islamic banks and conventional banks that have Sharia Business Units (UUS).

b. The Sharia Supervisory Board as referred to in paragraph (1) is determined by the General Meeting of Shareholders on the recommendation of the Indonesian Ulama Council.

c. The Sharia Supervisory Board as referred to in paragraph (1) will provide instructions and advice to the Directors and oversee bank activities in compliance with sharia principles.

d. Further provisions regarding the establishment of the Sharia Supervisory Board as referred to in paragraph (1) are regulated by Bank Indonesia.

Under this regulation it is clear that the DPS's position is strong and largely determines the development of sharia banks and sharia business units.

DPS based on AAOIFI (Accounting and Auditing Organization of Islamic Financial Institutions) has provided standards for DPS, composition, and related aspects such as regulations, reports and so on. According to this standard, sharia institutions must become free institutions consisting of scholars related to science and Islamic law. DPS can also consist of other experts in the field of Islamic financial institutions with scientific knowledge of Islamic laws relating to commercial transactions. DPS is mandated with the task of directing, researching and supervising the activities of Islamic financial institutions to ensure that they comply with Islamic rules and principles [23].

\subsection{The Role of the Sharia Supervisory Board in Wakalah Akad Application}

In the Islamic banking industry, the services provided by banks to customers are generally not contrary to Islamic principles. Because the services provided are not intended to benefit just like conventional banks, banks will apply a number of appropriate sharia contracts [24]. The Sharia Supervisory Board has a very important role in sharia banking in harmony with sharia contracts:

a. Making guidelines for product approval and operational of sharia banking based on provisions that have been prepared by the National Sharia Board (DSN).

b. Make regular reports every year about sharia banks that are under their supervision that the banks under their supervision have been running in accordance with sharia provisions. In the annual report (annual report) of Islamic institutions, the report from DPS must be made clearly.

c. The Sharia Supervisory Board should make a report on the development and application of the sharia financial system in sharia financial institutions especially sharia banks which are under supervision, at least every six months. Reports have been given to Bank Indonesia located in the provincial capital and or Bank Indonesia in the capital city of Indonesia, Jakarta.

d. The Sharia Supervisory Board is also responsible for reviewing and making proposals if there are new innovative products from the bank under their supervision. This assembly runs an initial assessment before the new product of the proposed Islamic bank is once again examined and registered by DSN.

e. Helping the socialization of sharia banking financial institutions / to the public.

f. Provide input for the development and progress of Islamic financial institutions.

In comparison, the duties of the sharia supervision agency in Malaysia are controlled by a body called the Shariah Advisory Council (MPS). Sharia Advisory Council is a body that was established in harmony with the founding of financial companies based on Islam. Its members consist of economic experts who also have expertise in the field of sharia. The State Bank Sharia Advisory Council has a higher position compared to the sharia power of trade banks. If there is a difference between the decision of the Sharia Advisory Council of the State Bank and the Sharia Authority of other banks, then the decision of the Sharia Advisory Board of the State Bank is used. Since the last few decades, MPS has been functioning as a referral body and has the authority to resolve the issue of sharia compliance in Islamic banking and finance in Malaysia. The Sharia Advisory Council of Bank Negara generally functions in providing fatwas relating to Islamic banking and insurance, making oversight, sharia compliance and auditing. This is because the latest developments in the Islamic finance industry show that there are many innovations in sharia financial products that are increasingly complex and diverse. In addition, MPS BNM also needs to carry out cooperation and communication among sharia experts and industry practitioners to continue the continuous merging of knowledge, experience and information, so as to increase the effectiveness of the supervision process to ensure sharia compliance. The role of MPS in particular is as follows:

a. List of sharia compliant securities. The Shariah compliant list has been issued by MPS twice a year, in May and September each year. This list is very important in assisting Islamic investors in identifying securities that comply with Sharia principles and thus increasing their confidence without hesitation in making investments.

b. Give advice on Capital Market Products. Among his tasks is to take two approaches, the first of which is that they will examine the validity of conventional instruments carried out by the capital market based on sharia perspective. The comments are concentrated on the structure, mechanism and use of these instruments whether there are principles that contradict the principles of sharia or not. Then the second approach is to compile and form a new instrument based on sharia.

c. Give advice in handling insurance. Among his duties is to advise and monitor matters dealing with insurance funds so that he is invested in instruments that are required only for sharia. So, if there is a payment to participants who need help, the money will come from lawful sources and not from investments that contain usury.

d. Give advice to Directors and financial institutions. Among the main functions of the Sharia Advisory Council is also to give advice to financial institutions such as commercial banks who want to issue a new banking product whether it meets the requirements of sharia or not. 
e. Verification of Shariah-compliant manuals. In providing a structured reference source to determine whether a banking product is in compliance with shariah compliant conditions or not, MPS will confirm a guideline that has been produced through discussions between members of the Sharia Advisory Council.

The role of the Sharia Advisory Board today is very challenging after the very complex practice and sharia financial products today. This condition gives a challenge to shariah experts to make the right decision. The more complex and sophisticated a syariah financial product and practice the more the role of BPS is challenging. But despite how challenging even though those roles, they are still willing to handle it because on their shoulders lies the full compliance of Sharia all Islamic financial products, practices and services.

Based on the information and comparison with the Malaysian kingdom above, DPS must meet certain qualifications. DPS must understand finance and banking even though he is an Islamic scholar and scholar because of the need to understand banking operations and financial economics. So, Islamic banking in Indonesia needs to restructure, improve and change for the better and appoint DPS who are competent in their fields. It is really necessary to optimize their roles and lead them to a positive image for the development of Islamic banking in Indonesia.

The mistake of Islamic banking in Indonesia in raising DPS is to appoint people who are very well known in Islamic community organizations, but are incompetent in the field of Islamic banking and finance. Most DPS do not understand sharia banking operations and oversee banks that are not optimal. Reality is beneficial for Islamic banking management, because they are free to do anything, because there is very loose supervision. But in the long run this will endanger the Islamic economic movement, not only for the relevant Islamic banking but also for the overall economic and Islamic banking movement in the future. So, it is not surprising if there is a view that Islamic banks are the same as conventional banks [25].

Article 35 number 1 rather than Bank Indonesia Regulation No. 03/11 / PBI / 2009 concerning Sharia Commercial Banks, DPS duties and responsibilities to provide advice and recommendations to the Board of Directors and oversee bank activities in accordance with Islamic principles. Heri Sudarsono said that the DPS function oversees the day-today operations of banks in accordance with sharia principles, and checks and makes recommendations for new products from these banks. But it must be admitted, that the happiness of Islamic bank DPS has played a role even though it is not optimal. This is the way it is managed by the Financial Services Authority, DSN MUI and Islamic banking institutions themselves. So, the Law is like a strategic position of DPS, it must be implemented correctly and quickly, for that every sharia bank management needs to formalize the role and involvement of DPS in ensuring the risk management of non-compliance with sharia principles. DPS must be given office space where there are staff who can provide financial data services, financial reports, contracts, editors, the process of implementing the contracts, and so on.

According to the results of Bank Indonesia's research in collaboration with Ernst and Young, it was discussed at a seminar at the end of 2008 at Bank Indonesia. One of the main problems in implementing risk management in Islamic banking is the role of DPS is not optimal and must be corrected in the future [26]. The role of DPS if it is not optimal for sharia compliance practices will result in the image and credibility of sharia banks will be affected in the eyes of the public and can reduce public confidence in the sharia banks. This is what Shanin A. Shayan said, CEO and Board Member of Barakat Foundation: "The biggest risk facing the global Financial System is not a fall in its earning power but most importantly a loss of faith and credibility on how it works". So according to him the biggest risk facing the global financial system is not a mistake about the ability to create profits, but more important is losing trust and credibility about how operations operate.

Based on research results found weaknesses of the Sharia Supervisory Board (DPS) is:

a. Until now there is no specific law that is used as a reference for supervision of Islamic banking cases,

b. DPS is only used as a complementary object in an existing Islamic banking institution, the structure can be filled without specific criteria based on expertise.

c. DPS members are appointed as figures who have charisma and popularity among the people, not because of their knowledge expertise in the fields of economics and Islamic banking,

d. DPS members are appointed and given salaries by the Islamic banks they supervise, making them less free and not objective in their supervision,

e. DPS members are people who are busy with their main profession, so they do not have enough time to carry out supervision. Supervision of Islamic banking is only done as a part-time job,

f. SSB has no freedom to act decisively on the results of its supervision. DPS can only give warnings but may not close down banking businesses that have problems, then supervision by DPS tends to be ignored,

g. Islamic banking is very vulnerable to mistakes that are shared,

h. Weaknesses in the legal level for Sharia compliance assessment by DPS due to the ineffectiveness and inefficiency of sharia supervision mechanisms in sharia banking,

i. Limited DPS expertise in auditing, accounting, economics, and business law,

j. Lack of effective work mechanism and structure for DPS in carrying out the internal control function of sharia in Islamic banks,

There are still many cases of violations of sharia principles committed by Islamic banking institutions, especially banks that convert to sharia or open a Sharia Business Unit (UUS). Such matters can influence the supervisory process and produce oversight that is confusing, merely a formality. This is not providing protection to bank users to be in accordance with Islamic principles. In addition, in his book Adrian Sutedi also stated, not a few DPS very rarely come to Islamic banks where DPS is placed. Even if they come only to come, they don't check the format and editorial contracts according to sharia principles, how to carry out bank restructuring, rescheduling, for determining margins, and so on. DPS sometimes only once a month, even months do not come directly to Islamic banks to be monitored. So, 
[2] Sumitro, W. (2004). Asas-asas Perbankan Islam dan Lembaga-lembaga Terkait. Jakarta: Raja Grafindo Persada.

[3] Ismail. (2013). Perbandan Syariah, Cetakan Kedua. Jakarta: Kencana Perdana Media Group.

[4] Karim, A. A. (2011). Bank Islam: Analisis Fiqih dan Keuangan. Jakarta: PT. Raja Grafindo Persada.

[5] Muhammad. (2006). Bank Syariah Analisis Kekuatan, Peluang, Kelemahan dan Ancaman, Cetakan Pertama. Yogyakarta: Ekonosia.

[6] Antonio, M. S. (1999). Bank Syariah Wacana Ulama dan Cendikiawan. Jakarta: Tazkia Institute.

[7] Ibid., hlm. 36.

[8] Ridwan, M. (2007). Kontruksi Bank Syariah Indonesia. Yogyakarta: Pustaka SM.

[9] Sujamto. (1986). Beberapa Pengertian di Bidang Pengawasan. Jakarta: Ghalia Indonesia.

[10] Situmorang, V. M. (1994). Aspek Hukum

Pengawasan Melekat. Jakarta: Rineka Cipta.

[11] Sutedi, A. (2011). Pasar Modal Syariah; Sarana Investasi Keuangan Berdasarkan Prinsip Syariah. Jakarta: Sinar Grafika.

[12] Dewi, G. (2007). Hukum Perikatan Islam di Indonesia. Jakarta: Kencana Perdana Group.

[13] Mertokusumo, S. (2004). Penemuan Hukum. Yogyakarta: Liberty.

[14] Marzuki, P. M. (2014). Penelitian Hukum. Jakarta: Prenada Group.

[15] Ibid

[16] Ibid hlm. 173.

[17] Yassar Widantyo, 2016, Aplikasi Akad Murabahah bil Wakalah dalam Pembiayaan Mikr di BRI Syariah KCP Kudus, Skripsi, Fakultas Ekonomi dan Bisnis, UIN Walisongo.

[18] Ahmad Fuad Noor Ghufron, 2016, Konstruksi Akad Murabahah dalam Perspektif Fatwa DSN-MUI No.04/2000 bil Wakalah dalam Pembiayaan Mikro di BMT El Bana Ngaliyan Semarang, Thesis, UIN Sunan Kalijaga

[19] Windi Yusmalanim, 2017, Pelaksanaan Akad Wakalah pada Pembiayaan Murabahah untuk Modal Kerja, (Studi pada PT. BPRS Carana Kiat Andalas Cabang Padang Panjang), Skripsi, Hukum Ekonomi 
[24] Hailani Muji Tahir, S. A. (2009). Aplikasi Fiqih Muamalat dalam SIstem Keuangan Syariah. Shah Alam : Pusat Penerbitan Universiti (UPENA).

[25] Muhammad Syakir Sula, 2004, Asuransi Syariah (Life and General), Jakarta: Gema Insani Press. hlm. 36 (Sula, 2004)

[26] Agustianto, Meningkatkan Kualitas dan Kompetensi Dewan Pengawas Syariah, http://www.agustiantocentre.com/?p=830, diunduh tanggal 13 Februari 2015 pukul 09.00

[27] Sutedi, A. (2011). Pasar Modal Syariah; Sarana Investasi Keuangan Berdasarkan Prinsip Syariah. Jakarta: Sinar Grafika. 